\title{
Hypothetical Strategies to Reduce the Greenhouse Gas Emissions from Mobile Sources on the Orizaba Valley
}

\author{
Joaquín Pinto-Espinoza ${ }^{1}$, Adán Reyes-Pavón ${ }^{1}$, Marco A. Benítez-Espíndola ${ }^{1}$, Gustavo Alvarado-Kinnell ${ }^{1}$ \& \\ Angélica M. Bello-Ramírez ${ }^{1}$ \\ ${ }^{1}$ Chemical and Biochemical Engineering Department, TecNM/Instituto Tecnológico de Orizaba, México \\ Correspondence: Joaquín Pinto-Espinoza, Ave. Oriente 9 \# 852, Col. Emiliano Zapata, C.P. 94330, Orizaba, \\ Veracruz, México. Tel: 01-272-724-4096. E-mail: pintoejo@yahoo.com
}

Received: July 1, 2018

doi:10.5539/ep.v7n2p42
Accepted: July 24, $2018 \quad$ Online Published: September 29, 2018

URL: https://doi.org/10.5539/ep.v7n2p42

\begin{abstract}
The Intergovernmental Panel on Climate Change established clear and solids conclusions on the 2013 report, it says that has been scientifically demonstrated with $95 \%$ of certainty, that human activities are the main cause of the global warming, observed since the middle of the XX century.

The Orizaba Valley is a Mexican region, located at the geographic center of Veracruz State, having Orizaba City as the main demographic population surrounded by other municipalities, becoming the fourth metropolitan populated area of Veracruz State. This region has the third position on economic, historic and cultural relevance at Veracruz State, just after the Veracruz Port and Xalapa City. It was one of the main places with a vast economic growing during the Viceroyalty of the New Spain, being an obligatory passing route and resting place between Veracruz Port and Mexico City.

This project estimates the magnitude of the Greenhouse Gas emissions coming from mobile sources at the Orizaba Valley. It includes the urban region of the municipalities of Ixtaczoquitlan, Orizaba, Río Blanco, Camerino de Mendoza and Nogales. The collected data was processed according to the Intergovernmental Panel on Climate Change methodology and it was possible to make the following projections: 1) One baseline scenario and 2) Three scenarios under hypothetical mitigation strategies that promise to achieve a reduction of GHG emission of $30 \%$ from the year 2020 to 2050 . Beyond this, also there is a significant reduction in fossil fuels consumption due to the efficient use of energy. All projections were made by using the Long-range Energy Alternatives Planning system software.

In addition of the achievement on the GHG emissions reduction goal, it is possible to glimpse an economic recovery, if and only if, the decision makers of the governments decide to participate in the international trade of carbon market.
\end{abstract}

Keywords: climate change, global warming, greenhouse gas, LEAP, mitigation

\section{Introduction}

The diversity of the natural process, organizational, and productive has implicated considerable modifications to the biosphere. The human being has become the dominant biological specie and it has been established at almost on the full planet. Due to their global intervention scale, persistence of their actions, and the accumulative character of their results, maybe it is the major transcendental environmental experiment undertaken for the humanity to influence on the atmosphere transformation.

The terrestrial atmosphere is the common global environmental goods. It is a thin film, constituted by a gaseous mass of nearly homogeneous composition due to the virtue of the gases diffusion properties, the convective vertical movement, the general circulation of the atmosphere and other mechanisms. All gaseous contaminant sent to the atmosphere is diluted and distributed in its extension. Any transformation suffered by the atmosphere, for example, concentration of the gases, will affect the biosphere and consequently to the humanity.

The average atmospheric molecular composition includes mainly two gases, nitrogen (79\%) and oxygen (20\%). The $1 \%$ residual is constituted for diverse gases, the most representative are argon $(0.9 \%)$ and carbon dioxide $(0.03 \%)$. The latter one, even present at low proportions, becomes crucial on the global warming process. 
Consequently the climate change is the result of the intensive use of the atmosphere as recipient of greenhouse gas emission (GHG). The problem consists in the accumulative volume of GHG -especially carbon dioxideemitted during the last one hundred and fifty years that overpass the biosphere capture capacity, having a constant increase of concentrations of GHG, hindering the emission of energy to the space and modifying the natural process of the greenhouse effect (Caballero, 2007).

There is no doubt that this induced situation is due to the anthropogenic emission of GHG, the loss of biodiversity, the ecosystems degradation, and the environmental services are the environmental most transcendental problem of the XXI century and the major challenge facing the humanity.

Because of the adverse, obvious, and foreseeable effects, the climate change transcends the environmental scope and represents a growing threat to the human race. Thus, there is no country that can face this problem alone. For its temporal dimension, it is crucial to plan for the long term and also act immediately. Essentially, among the GHG, there are others pollutant criteria which generates a great impact in the community health and contributes on the climate change acceleration (Martínez et al., 2004).

Martínez-Salgado (2011) reported that in average, in Mexico, the emissions of vehicles of 10 years or older are greater than those of the most recent vehicles: carbon monoxide (CO), between 3 and 4 times; total hydrocarbons (HC), between 4 and 6 times; and nitric oxide (NO), up to 3 times more. On the other hand, in the border cities there are larger, older vehicles, a higher percentage of foreign origin. The motorization (vehicle/habitants) is also greater in the cities of the northern border with respect to the rest of the country, mainly due to the greater availability of used vehicles.

Transport accounts for nearly a quarter of current energy-related carbon dioxide emissions with car travel constituting more than three quarters of all vehicle kilometers travelled. Interventions to change transport behavior, and especially to reduce car use, could reduce $\mathrm{CO}_{2}$ emissions from road transport more quickly than technological measures. It is unclear; however, which interventions are more effective in reducing car use and what the likely impact of these interventions would be on $\mathrm{CO}_{2}$ emissions (Graham-Rowe et al, 2011).

This work was focused on the evaluation of the emissions contributions of GHG produced by the vehicular stock at the Orizaba Valley and its future projections up to the year 2050. Furthermore, three hypothetical mitigation strategies were analyzed in order of reducing gradually the GHG emissions.

Table 1. Emission factors for $\mathrm{CO}_{2}$ by consumption

\begin{tabular}{ccccccc}
\hline \multirow{2}{*}{ Fuel } & \multicolumn{2}{c}{ IPCC, 1996 } & \multicolumn{2}{c}{ IPCC, 2006 } & \multicolumn{2}{c}{ INECC, 2014 } \\
\cline { 2 - 7 } & kg/TJ & $\begin{array}{c}\text { Pounds/ } \\
\text { Million Btu }\end{array}$ & kg/TJ & $\begin{array}{c}\text { Pounds/ } \\
\text { Million Btu }\end{array}$ & kg/TJ & $\begin{array}{c}\text { Pounds/ } \\
\text { Million Btu }\end{array}$ \\
\hline Gasoline & 68607 & 159.58 & 69300 & 161.19 & 73791 & 171.63 \\
Diesel & 73326 & 170.55 & 74100 & 172.35 & 72850 & 169.45 \\
\hline
\end{tabular}

\section{Methods}

The vehicular stock was analyzed from the municipal and state base data system (SIMBAD, Spanish acronyms) considering since 1999 until 2015 (SIMBAD, 2017). Meanwhile, the fuel sales were provided by PEMEX Storage and distribution terminal, located at Ixtaczoquitlan, Veracruz. It covers from 1996 to 2016 (PEMEX, 2017).

The emission factor of $\mathrm{CO}_{2}$ used on this research was collected from the data recommended by the Intergovernmental Panel on Climate Change (IPCC, 1996; IPCC, 2006) and the National Institute of Ecology and Climate Change (INECC, 2014), as shown in Table 1. Similarly, the emission factors used for Methane and Nitrogen Oxide are presented on Table 2. 
Table 2. Emissions factors for $\mathrm{N}_{2} \mathrm{O}$ and $\mathrm{CH}_{4}$ by travelled distance (Heaps, 2016)

\begin{tabular}{ccccc}
\hline \multirow{2}{*}{ Combustible } & \multicolumn{3}{c}{$\mathbf{N}_{\mathbf{2}} \mathbf{O}$} & \multicolumn{3}{c}{$\mathbf{C H}_{\mathbf{4}}$} \\
\cline { 2 - 5 } & $\mathbf{m g} / \mathbf{k m}$ & $\mathbf{g} / \mathbf{m i}$ & $\mathbf{m g} / \mathbf{k m}$ & $\mathbf{g} / \mathbf{m i}$ \\
\hline Gasoline & 12.66 & 0.020374 & 160 & 0.257495 \\
Diesel & 2.00 & 0.003218 & 2.5 & 0.004023 \\
\hline
\end{tabular}

The most useful tool for developing this project was the software LEAP (Long-range Energy Alternatives Planning System). This software is widely-used for energy policy analysis and climate change mitigation assessment developed at the Stockholm Environment Institute. LEAP has been adopted by thousands of organizations in more than 190 countries worldwide. Its users include government agencies, academics, non-governmental organizations, consulting companies, and energy utilities. It has been used at many different scales ranging from cities and states to national, regional and global applications (Heaps, 2016).

In order of working with LEAP the following methodology was developed.

1) Delimit the initial basic parameters to establish a studio area like city, base year, end year, among others.

2) Set the activity levels on the current accounts scenario. Here it is possible to define the demand, meaning the vehicular stock (cars, pick-up trucks, passenger transport truck, and motorcycle).

3) Set the type of technology (Internal combustion or electric). It is necessary to define the type of used fuel, including the environmental loading as $\mathrm{CO}_{2}, \mathrm{CH}_{4}$ and $\mathrm{N}_{2} \mathrm{O}$. Also includes fuel economy, travelled distance, life cycle of the cars, among others.

4) State the projections on the Base Line Scenario (BLS). Under this scenario the main consideration assumes that the vehicular and fuel sales will increase according to the historical information, this means no action will be taken to retard the economic and technological growing of the region.

5) LEAP has three choices in the methodologies to evaluate the energy demand analyses, which are described below. On this study, the transport analysis was used.

a) Activity Level Analysis, which itself consists of either Final Energy Demand Analysis, or Useful Energy Demand Analysis in which energy consumption is calculated as the product of an activity level and the annual energy intensity (energy use per unit of activity).

b) Stock Analysis, where energy consumption is calculated by analyzing the current and projected future stocks of energy-using devices and the annual energy intensity of each device (defined as energy per device).

c) Transport Analysis, where energy consumption is calculated as the product of the number of vehicles, the annual average mileage (i.e. distance traveled per vehicle) and the fuel economy of the vehicles (e.g. liters per $\mathrm{km}$ or $1 / \mathrm{MPG})$.

6) The energy consumption was calculated as the product of an activity level and the annual energy intensity (energy use per unit of activity). Overall activities are defined as the products of the individual activities entered along a complete branch of the Demand tree. The total energy consumption is thus calculated by the equation 1 .

$$
\text { Energy consumption }=(\text { activity level) } x \text { (energy intensity) }
$$

There are two basic variations to this methodology: in a Final Energy Demand Analysis you specify energy intensities at the device level as the amount of fuel used per unit of activity; in a Useful Energy Demand Analysis you specify useful energy intensities at the next highest branch level (typically the end-use level), and then specify the efficiencies of each device (Heaps, 2016).

7) Establish the models for the mitigation scenario. For this research, three different scenarios were postulated in order to reduce the GHG emission.

a) Electric Technology Scenario (ETS): It means to introduce electric cars starting on 2018 until to reach $30 \%$ of the stock at the year 2050 , only applied for cars and pick up trucks.

b) Smart Usage Scenario (SUS): It means to use adequately the vehicle reducing its annual car travelling at least $30 \%$ on average, reached at the year 2050, except passanger transport and motorcycle.

c) Improved Performance Scenario (IPS): It means to technologically modify the cars functioning per fuel consumed to improve its performance up to $30 \%$ at the year 2050 , applied to all vehicular transport. This approach should be accord with the quality of fuels, as was reported by SEMARNAT-PEMEX, 2006. 
Table 3 resumes the main GHG taken in consideration in this research. It shows the emission source and the Global Warming Potential (IPCC, 2006).

According to the international reports, the Energy sector is the main source of GHG emission at 70 countries, the agriculture sector at 45 countries and only 6 countries reports the waste sector is the main contributor. The absorption of the FOLU (forestry and other land use) sector, in all countries, equates the emission of the same sector (FCCC, 2015).

Globally the transport sector becomes the main contributor to the global warming. On $2007,23 \%$ of the worldwide emissions of GHG (related to energy consumption) came from the transport sector. From these emissions $45 \%$ comes from passenger vehicles and its expecting to continue to be the predominant GHG source on the future. The actual prediction estimates that the underdeveloped countries will increase its emission contribution from $35 \%$ in 2000 to $63 \%$ in 2030 .

Table 3. Green house gas characteristics

\begin{tabular}{cccl}
\hline Type of GHG & $\begin{array}{c}\text { Year of life } \\
\text { before } \\
\text { degrading }\end{array}$ & $\begin{array}{c}\text { Global } \\
\text { Warming } \\
\text { Potential }\end{array}$ & \multicolumn{1}{c}{ Emission Source } \\
\hline $\begin{array}{c}\text { Carbon Dioxide } \\
\left(\mathrm{CO}_{2}\right)\end{array}$ & 500 & 1 & $\begin{array}{l}\text { Transport, Electric Energy Generation, Manufacturing } \\
\text { and Construction, Consumption of the Energy Industry, } \\
\text { Conversion of Forests and Pastures, Residential sector, } \\
\text { Commercial sector, Agricultural sector }\end{array}$ \\
\hline $\begin{array}{c}\text { Methane } \\
\left(\mathrm{CH}_{4}\right)\end{array}$ & $7-10$ & 21 & $\begin{array}{l}\text { Fugitive Emissions for Oil and GN, Enteric } \\
\text { Fermentation, Solid Waste Disposal, Sewage treatment, } \\
\text { Fugitive Emissions of Solid Fuels }\end{array}$ \\
\hline $\begin{array}{c}\text { Nitrogen Oxide } \\
\left(\mathrm{N}_{2} \mathrm{O}\right)\end{array}$ & $140-190$ & 310 & $\begin{array}{l}\text { Agricultural Soils (Excreta and Nitrogenized Fertilizers), } \\
\text { Transport, Manure Management, Sewage treatment }\end{array}$ \\
\hline
\end{tabular}

The total emissions inventory for Mexico, reported $665304.92 \mathrm{Gg}$ of $\mathrm{CO}_{2}$ equivalent, where the Mobile source represented $26.2 \%$, Electricity generation $19.0 \%$, Industry $17.3 \%$, Petroleum and gas production $12.1 \%$, Agriculture $12 \%$, FOLU 4.9\%, Waste $4.6 \%$ and the Residential and Commercial sector $3.9 \%$. The relation between the total emission and the GHG were: the $\mathrm{CO}_{2}$ represented $75.1 \%$ followed by $\mathrm{CH}_{4}$ with $19.0 \%, \mathrm{~N}_{2} \mathrm{O}$ with $4.5 \%$ and finally HFC and $\mathrm{SF}_{6}$ with $1.4 \%$ (INECC-SEMARNAT, 2015).

Adaptation to the weather variability and extreme events, on the short term, should be the foundation to reduce vulnerability to the climate change on the long term. This is a systematic process which implies several actions and strategies coherently coordinated between government and society. Consequently, the adaptation will serve to reduce the impact of weather variability that entails natural extreme events that influences to social, natural, and economics systems (IPCC, 2014).

On the other hand, mitigation implies to establish strategies and actions to reduce the GHG anthropogenic contribution. The world goal should be gradually reverse the global warming. Of course, the resistance to change of habits and customs are the main barriers that opposed to the mitigation strategies implementation. The magnitude of the climate variability is not enough to convince government leaders and society about the problematic; maybe its resistance to do something regarding the anthropogrnic GHG is due to economic interest (Pinto et al, 2012).

Vehicles are one of the main anthropogenic sources of emission of atmospheric pollutants precursors of ozone formation. Although these emissions are the direct result of the use of fossil fuels, such as gasoline and diesel, there are other determining factors in the amount of pollutants generated for a motor vehicle, such as age, technology, use and maintenance.

For those reasons and since solutions are limited on the global context, it is convenient to work at regional scale, having the hope that exemplary actions will serve as samples to be duplicated in other regions.

\section{Results}


Figure 1 shows the vehicular stock on the Orizaba Valley (Reyes and Pinto, 2017). It can be seen that cars has the greater growing tendency followed by pick-up trucks. Extrapolating those data until 2050 year was able to predict the future stock and also the future sales of vehicles.

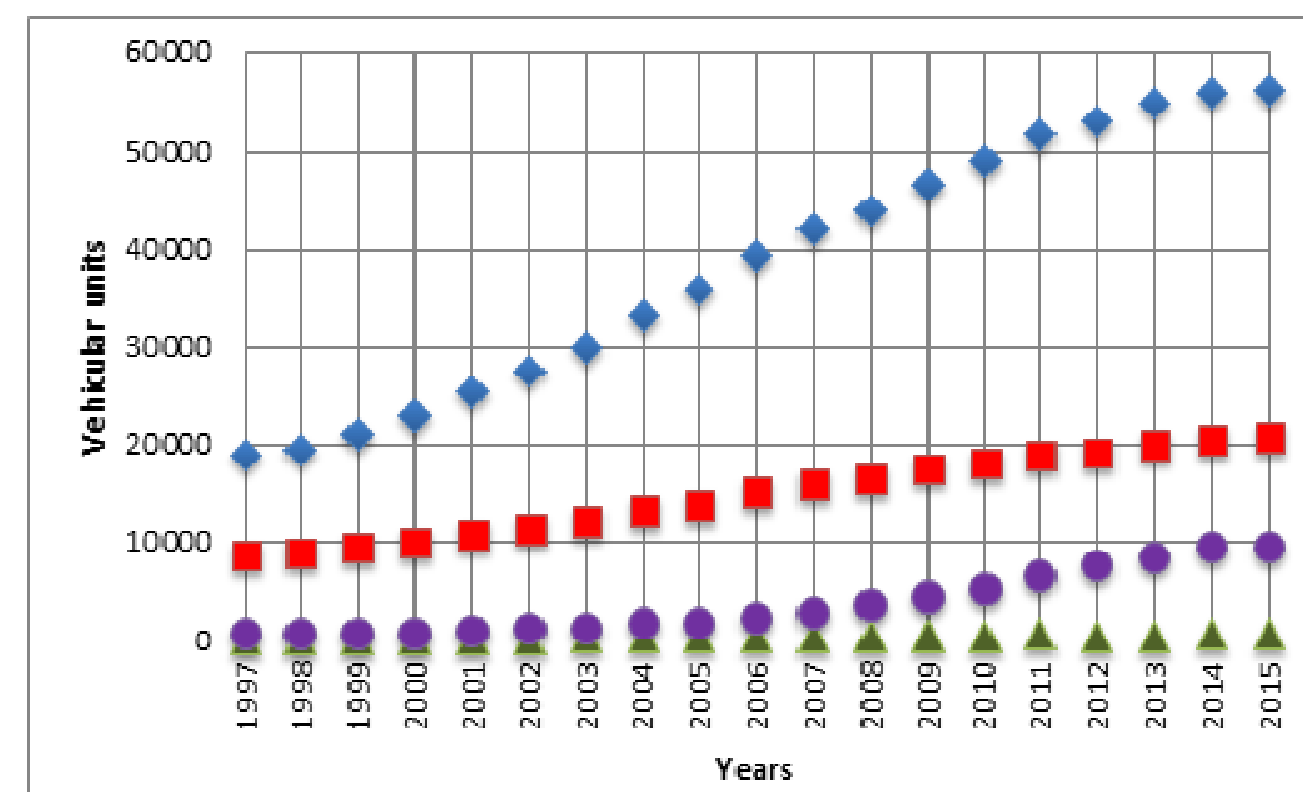

\section{cars Dick-up trucks $\Delta$ passanger transport omotorcycle}

Figure 1. Vehicular inventory on the Orizaba Valley

The growing vehicular stock annual rate is approximately 3.5\%, which means to pass from 90358 to 178593 vehicular units in a period of years from 2015-2050. This situation imposes two problems that shall be handled; the first one implies increasing of fuel requirement due to the energy demand growth as the vehicular inventory raise, and the second one, the GHG emissions will also increase as consequence of major combustion, as shown on Figure 2 and 3 as is described by the Base Line Scenario (BLS). 


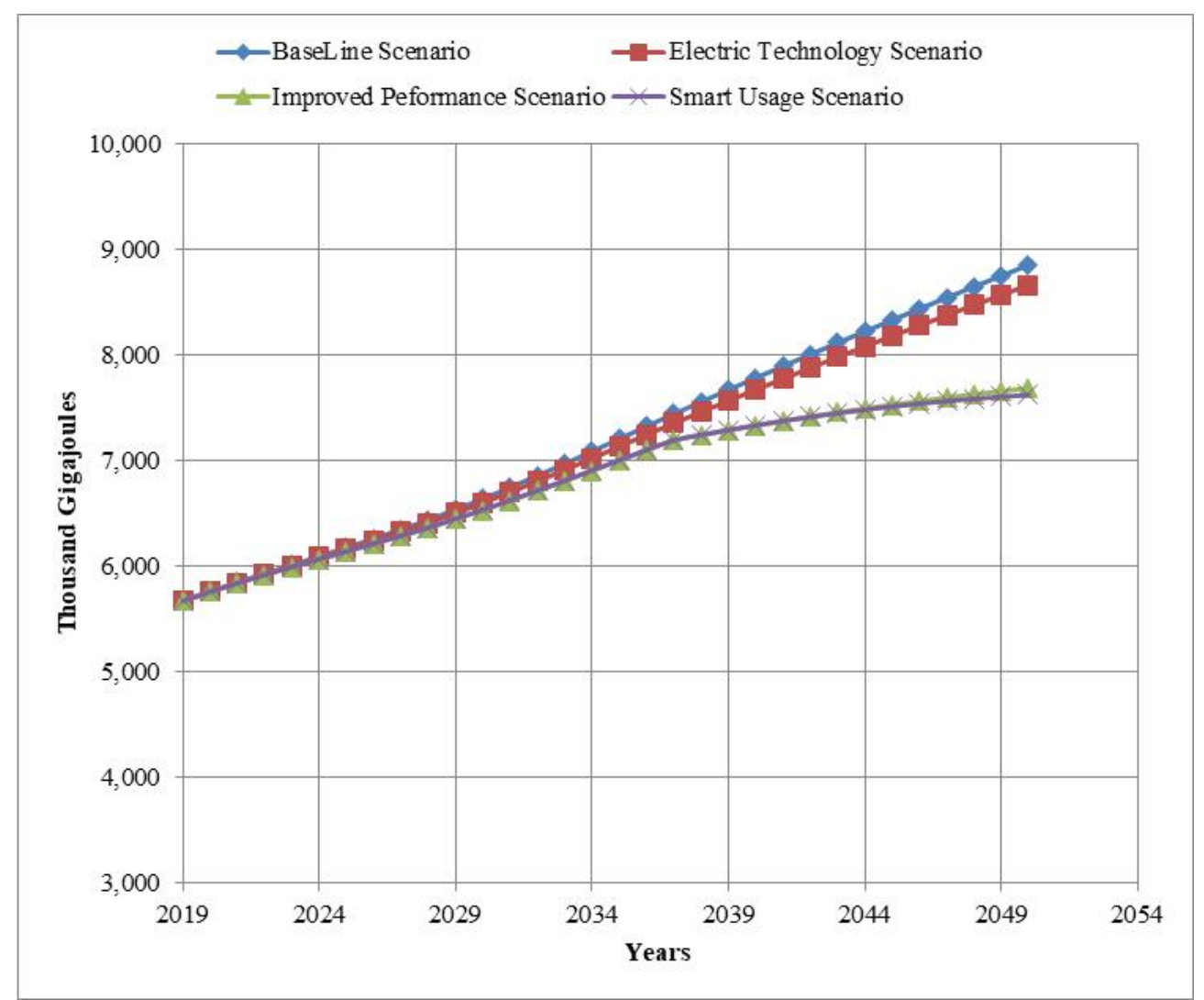

Figure 2. Energy demand on the Orizaba Valley

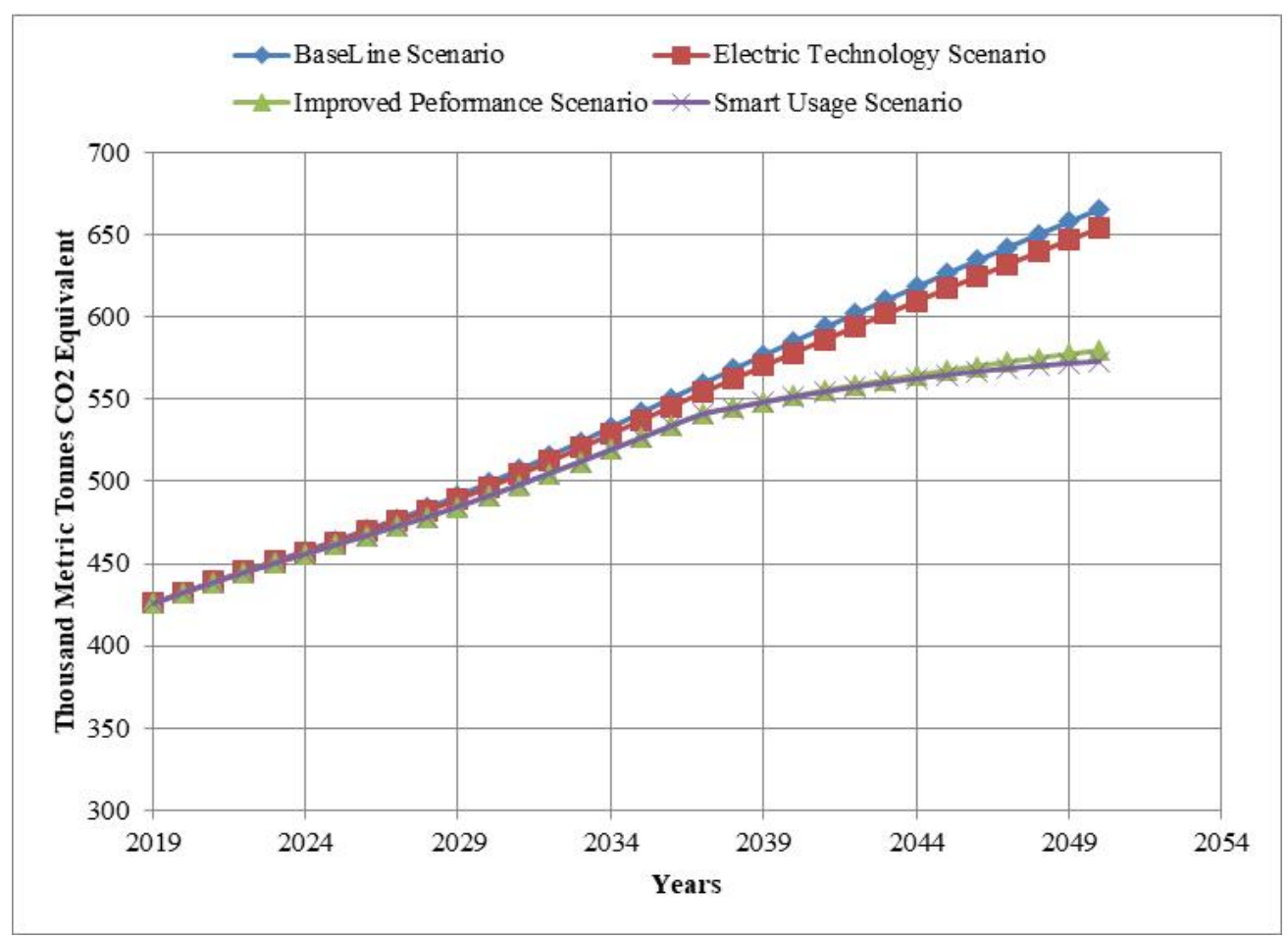

Figure 3. GWP on the Orizaba Valley

In order of reverse these situations, three scenarios were studied and evaluated, each one achieve its own goals 
on both scopes; energy saving and GHG emissions mitigation. The effects of these hypothetical scenarios are summarized on the Table 4, where the Smart Use Scenario (SUS) has the greatest reduction, compared between them, with approximately $46.7 \%$, followed by Improved Performace Scenario (IPS) with $44.9 \%$ and finally Electric Technology Scenario (ETS) with $8.4 \%$. Consequently since each scenario standing alone do not impact considerably to reach the general mitigation objective, it's recommended to develop a combined strategy taking all advantages of the three scenarios, reducing at least 1.85 million of metric tons of $\mathrm{CO}_{2}$ equivalent. Of course, this situation will carry an energy saving of around 25 million of Gigajoules.

Ong, Mahlia and Masjuki (2011) proposed four potential emission mitigation strategies for the road transport in Malaysia, which were $10 \%$ of passenger cars shift to public transport, motorcycles shift to public transport, passenger cars shift to natural gas vehicles and vehicles renewal with Euro 4 emission standard. The 10\% was chosen as a convenient figure for calculation to predict the response and effects of each potential mitigation strategies. Passenger cars renewal was one of the effective emission mitigation strategies to reduce the road transport emission in Malaysia. With renewal of $10 \%$ in the oldest cars, it can save $1.3 \%$ of fuel consumption and total $\mathrm{CO}_{2}$ equivalents emissions decrease 3.5\%. Yedla, Shrestha and Anandarajah (2005) conducted an analysis between a local emission mitigation strategies (LEMS) versus a global emission mitigation strategies (GEMS). The comparative analysis revealed that strategies targeted at the mitigation of local pollution like total suspended particulate matter (TSP) and hydrocarbons (HC) also shows greater potential in reducing carbon dioxide $\left(\mathrm{CO}_{2}\right)$ emissions (as non-target emission). In GEMS, $20 \% \mathrm{CO}_{2}$ reduction resulted in $14.9 \%$ reduction in TSP emission. In LEMS with a $20 \%$ TSP reduction, $\mathrm{CO}_{2}$ emission reduction was found to be $15.2 \%$. TSP mitigation strategy not only performed well with non-target global emission but also within local emissions with SOx reduction much higher than that of target pollutant (TSP itself). El-Fadel and Bou-Zeid (1999) studied several mitigation measures to reduce GHG emissions from the road transportation sector in Lebanon. Improvement of the fleet by inspection and maintenance programs, fuel quality regulations and other policies can reduce the projected radiative forcing of GHG emissions by $31 \%$ in 2020 compared to a slower and less aggressive legislation. Nevertheless, travel volume increase was found to be more important than technology improvements in the fleet. Hence the need to reduce activity volume, mainly through better urban planning and improved public transport, if the emissions are to be held at a relatively constant level.

Table 4. Projections of the Energy Demand and the GWP for the Orizaba Valley

\begin{tabular}{ccccccccc}
\hline & \multicolumn{3}{c}{$\begin{array}{c}\text { Energy Demand } \\
\text { (Thousand Gigajoules) }\end{array}$} & & \multicolumn{3}{c}{$\begin{array}{c}\text { Global Warming Potential } \\
\text { (Thousands of metric tons CO }\end{array}$ equivalent) } \\
\hline YEAR & BLS & ETS & IPS & SUS & BLS & ETS & IPS & SUS \\
\hline 2020 & 5759.16 & 5758.48 & 5757.29 & 5757.47 & 432.49 & 432.45 & 432.35 & 432.36 \\
2025 & 6175.25 & 6161.80 & 6138.38 & 6140.80 & 464.02 & 463.16 & 461.30 & 461.42 \\
2030 & 6637.24 & 6598.14 & 6529.33 & 6533.76 & 498.93 & 496.45 & 490.98 & 491.14 \\
2035 & 7205.60 & 7132.23 & 7000.25 & 7003.82 & 541.75 & 537.14 & 526.63 & 526.57 \\
2040 & 7782.25 & 7670.50 & 7332.22 & 7334.48 & 585.14 & 578.17 & 552.01 & 551.48 \\
2045 & 8330.16 & 8178.90 & 7529.38 & 7511.70 & 626.32 & 616.99 & 567.39 & 564.84 \\
2050 & 8852.01 & 8661.88 & 7685.12 & 7620.87 & 665.52 & 653.91 & 579.65 & 573.07 \\
\hline
\end{tabular}

\section{Discussion}

The results obtained in this project glimpse the possible future scenario following the trend of economic growth and conventional technology (BLS) that is, without implementing any action, leading to reverse the damage caused to the planet. Furthermore, the results show that by implementing specific actions contributing to reduce GHG emissions, such as SUS, ETS and IPS, it is possible to counteract the accumulation of GHGs in the atmosphere and thereby reduce global warming and consequently the impacts of climate change. Obviusly the reduction of GHG emission become more significant considering all regional activities as is addresed by Burle and Lèbre (2007) that discussed a brief report of the experience in making an inventory from secondary data and building up scenarios that has been undertaken in Rio de Janeiro, Brazil. The mitigation measures were propose considering the major activities. In the transport sector several actions were consider, for example; change of type of fuel, rationalization of routes, increase efficiency. Consequently direct benefits could be possible such as 
the quality of city environments due to reductions of the local atmospheric pollutants.Isolated mitigation actions will not significantly influence the damage caused by anthropogenic activities, it is important that all regions of the countries of the planet work in a coordinated manner for a common objective. Only in this way will it be possible to preserve and conserve the adequate conditions of the planet for the subsistence of humans and all the ecosystems inhabiting the common home.

\section{Conclusion}

It is possible to reduce aproximately 1.85 million of metric tons of $\mathrm{CO}_{2}$ equivalent. Of course, this situation will carry an energy saving of around 25 million of Gigajoules. Economically speaking, it is possible that with the reduction of the $\mathrm{CO}_{2}$ emitted, a profit in the carbon market may be obtained, being greater than 12.6 million USD, considering that the average price of the carbon bonus in 2017 was 5.83 euros, according to the reported by the europan $\mathrm{CO}_{2}$ trading system.

\section{Acknowledgments}

Thanks to the TecNM/Instituto Tecnlógico de Orizaba, for the financing of the project with folio number 5824.16-P and provide the physical and human infrastructure to develop it. We would also like to thanks the federal and state government institutions such as PEMEX, SEMARNAT and SIMBAD for providing us with important information that were the basis of this study.

\section{References}

Caballero, M., Lozano, S., \& Ortega, B. (2007). Efecto invernadero, calentamiento global y cambio climático, una perspectiva desde las ciencias de la tierra. Vol. 8. Núm. 10. UNAM Revista digital universitaria. Mexico, D.F. Retrieved from http://www.revista.unam.mx/vol.8/num10/art78/int78.htm

Carolina Burle Schmidt Dubeux and Emilio Le bre La Rovere (2007). Local perspectives in the control of greenhouse gas emissions - The case of Rio de Janeiro. Elseiver Vol. 24, No. 5, p. 353-364, 2007. https://doi.org/10.1016/j.cities.2007.01.012

El-Fadel, M., \& Bou-Zeid, E. (1999). Transportation GHG emissions in developing countries. The case of Lebanon. Pergamon-Elsevier-Transportation Research Part D 4 (1999) 251 $264 . \quad$ PII: S1361-9209(99)00008-5

FCCC. (2015). Synthesis Report on the Aggregate Effect of the Intended Nationally Determined Contributions. United Nations, Conference of the Parties. Germany.

Graham-Rowe, E., Skippon S., Gardner, B., \& Abraham, C. (2011). Can we reduce car use and, if so, how? A review of available evidence. Elseiver Volume 45, Issue 5, June 2011, Pages 401-418. https://doi.org/10.1016/j.trpro.2016.05.273

Heaps, C. G. (2016). Long-range Energy Alternatives Planning (LEAP) system. [Software version: 2018.1.8] Stockholm Environment Institute. Somerville, MA, USA. Retrieved from https://www.energycommunity.org

INECC. (2014). Factores de emisión para los diferentes tipos de combustibles fósiles y alternativos que se consumen en México. Editor INECC, Mexico, D.F.

INECC-SEMARNAT. (2015). Primer Informe Bienal de Actualización del Inventario Nacional ante la Convención Marco de las Naciones Unidas sobre el Cambio Climático. Editor INECC, México, D.F.

IPCC. (1996). Guidelines for National Greenhouse Gas Inventories. Editor IPCC. Geneva, Switzerland. Retrieved from https://www.ipcc-nggip.iges.or.jp/public/gl/invs1.html

IPCC. (2006). Guidelines for National Greenhouse Gas Inventories. Editor IPCC. Geneva, Switzerland. Retrieved from https://www.ipcc-nggip.iges.or.jp/public/2006gl/index.html

IPCC. (2014). Cambio climático: Impactos, adaptación y vulnerabilidad Contribución del Grupo de trabajo II al Quinto Informe de Evaluación del Grupo Intergubernamental de Expertos sobre el Cambio Climático. Editor IPCC.

Martínez, J., Fernández, A., \& Osnaya, P. (2004). Cambio climático una visión desde México. Editor INECC-SEMART. México, D.F. $\quad$ Retrieved http://www.ccmss.org.mx/documentacion/331-cambio-climatico-una-vision-desde-mexico/

Martínez-Salgado, H. (2011). Estudio de emisiones y características vehiculares en ciudades mexicanas. Fase IV: medición de emisiones en cinco ciudades y análisis de resultados globales. Editor México, D.F. 
Ong, H. C., Mahlia, T. M. I., \& Masjuki, H. H. (2011). A review on emissions and mitigation strategies for road transport in Malaysia. Elsevier Renewable and Sustainable Energy Reviews, 15, 3516-3522. https://doi.org/10.1016/j.rser.2011.05.006

PEMEX. (2017). Terminal de Almacenamiento y Distribución de PEMEX ubicada en Carretera Federal México-Veracruz Km. 321. Ixtaczoquitlán, Veracruz de la Llave, México.

Pinto, E. J., López, S. A., \& Martínez, P. A. (2012). Reporte Final del Programa Estatal de Acción ante el Cambio Climático de Durango PEACC-Durango. SEMARNAT-Durango. Durango, Dgo., México.

Reyes, P. A., \& Pinto, E. J. (2017). Reporte técnico de residencia profesional "Cálculo regional de las emisiones de GEI proveniente de fuentes móviles terrestres y su proyección futura bajo escenarios de cambio climático". I.T. de Orizaba. Orizaba, Ver., México.

SEMARNAT- PEMEX. (2006). Estudio de evaluación socioeconómica del proyecto integral de calidad de combustibles. Reducción de azufre en gasolinas y diésel. Editor INECC, México, D.F.

SIMBAD. (2017). Sistema Estatal y Municipal de Bases de Datos. Municipio de Orizaba, Veracruz de la Llave, México.

Yedla, S., Shrestha, R. M., \& Anandarajah, G. (2005). Environmentally sustainable urban transportation - comparative analysis of local emission mitigation strategies vis-a -vis GHG mitigation strategies. Elsevier-Transport Policy, 12, 245-254. https://doi.org/10.1016/j.tranpol.2005.02.003

\section{Copyrights}

Copyright for this article is retained by the author(s), with first publication rights granted to the journal.

This is an open-access article distributed under the terms and conditions of the Creative Commons Attribution license (http://creativecommons.org/licenses/by/4.0/). 